Economics Development Analysis Journal 9(1)(2020)

\title{
Family Hope Program Evaluation in Poverty Alleviation: Benefit Incidence Analysis
}

\author{
Luthfi Faishal Azhar $^{1,}$ Lilis Siti Badriah ${ }^{\otimes_{2}}$, Bambang ${ }^{3}$ \\ ${ }^{1,2,3}$ Economics and Bussiness Faculty, Universitas Jenderal Soedirman
}

\begin{tabular}{ll}
\hline $\begin{array}{l}\text { Article } \\
\text { Information }\end{array}$ & $\begin{array}{l}\text { Abstract } \\
\text { This research was conducted in the Cigalontang Sub-district, Tasikmalaya Regency, West Java }\end{array}$ \\
$\begin{array}{l}\text { History of Article } \\
\text { Received October 2019. } \\
\text { Accepted December 2019 } \\
\text { Pusblished February }\end{array}$ & $\begin{array}{l}\text { Province. This study aims to analyze: (1) the accuracy of the Family Hope Program in achieving } \\
\text { poor, progressive, or regressive), (3) the effectiveness of the Family Hope Program implementation. } \\
\text { The number of respondents consisted of 195 Beneficiary Families of the Family Hope Program . } \\
\text { This study uses primary data, which were collected using interview and questionnaire methods. This } \\
\text { study uses analysis methods in the form of Proportion Analysis, Benefit Incidence Analysis, and }\end{array}$ \\
$\begin{array}{l}\text { Keywords: } \\
\text { Effectiveness, Family, }, \\
\text { Poverty }\end{array}$ & $\begin{array}{l}\text { Appraisal Effectiveness Program. Based on the results of the study, it can be concluded that : (1) } \\
\text { The pattern of the Family Hope Program acceptance in the Cigalontang Sub-district is right on } \\
\text { target. Because the proportion of the population with income below the poverty line per capita } \\
\text { receives the most benefits from the Family Hope Program according to the target, namely, very- } \\
\text { poor households. (2) The Family Hope Program in the Cigalontang Sub-district is Pro-Poor, (3) } \\
\text { The Family Hope Program in the Cigalontang Sub-district is classified as an effective program. }\end{array}$
\end{tabular}

\begin{tabular}{|c|c|}
\hline Corresponding author: & \\
\hline J1. Profesor DR. HR Boenyamin No.708, Dukuhbandong, & ISSN \\
\hline $\begin{array}{l}\text { Grendeng, Purwokerto, Central Java } \\
\text { E-mail: lilissitibadriah@gmail.com }\end{array}$ & \\
\hline
\end{tabular}




\section{INTRODUCTION}

Poverty is a problem faced by every country, especially developing countries with a very high population density. According to Kuncoro (2006), the causes of poverty are the vicious circle of poverty. Underdevelopment, market imperfections, and lack of capital lead to low productivity. Low productivity causes low income. Low-income results in smaller savings and investment. Little savings and investments affect the increasing number of poor people.

Poverty significantly affects the poor population itself. Poor people will find it difficult to access education, health, and other public services. The lack of social security provided by the government cannot meet primary needs such as clothing, food, and shelter. According to Statistics Central Agency (2016), poverty is a condition of a person or group of people who cannot fulfill their fundamental rights to maintain and develop a dignified life. This definition shows that poverty is a multidimensional problem.

Poverty is also a problem faced by the Indonesian State. Based on Statistics Central Agency data (2018), the number of poor people in Indonesia is concentrated on Java, especially in the provinces of East Java, Central Java, and West Java. This condition can be seen in Table 1 .

Table 1. explains that the number of poor people in Java is very high. East Java Province is the region with the most significant amount of poor people, which is $4.617,01$ thousand people. Second in Central Java with a population of $4.450,72$ thousand poor people. West Java third ranks in the most significant number of poor people in Java, with 4.168,44 thousand people.

Table 1. Number of Poor Population by Province in Indonesia 2015-2017 (10 highest order)

\begin{tabular}{lccc}
\hline \multirow{2}{*}{ Province } & \multicolumn{3}{c}{ Number of Poor Population (thousand people) } \\
\cline { 2 - 4 } & 2015 & 2016 & 2017 \\
\hline East Java & $4.789,12$ & $4.703,03$ & $4.617,01$ \\
Central Java & $4.577,04$ & $4.506,89$ & $4.450,72$ \\
West Java & $4.435,70$ & $4.224,33$ & $4.168,44$ \\
North Sumatra & $1.463,67$ & $1.455,95$ & $1.453,87$ \\
East Nusa Tenggara & $1.159,84$ & $1.149,92$ & $1.150,79$ \\
Lampung & $1.163,49$ & $1.169,60$ & $1.131,73$ \\
South Sumatra & $1.145,63$ & $1.101,19$ & $1.086,92$ \\
Papua & 859,10 & 911,33 & 897,69 \\
Aceh & 851,59 & 848,44 & 872,61 \\
South Sulawesi & 797,72 & 807,03 & 813,07 \\
\hline
\end{tabular}

Source: Central StatisticsAgency, 2018

West Java consists of four areas of the Government Development Coordinating Board consisting of Region I Bogor, Region II Purwakarta, Region III Cirebon, and Region IV Priangan (Sekilas Jabar, 2017). Based on Central Statistics Agency data (2017), it is known that Region IV Priangan is the most significant contributor to the number of poor people in West Java. Of the eleven Regencies/ Cities in Region IV Priangan, Tasikmalaya Regency is ranked fourth with the most significant number of poor people after Garut Regency, Bandung Regency, and West Bandung
Regency, amounting to 189.35 thousand inhabitants. Poverty in Tasikmalaya Regency is the sum of all poor people in the areas in the Tasikmalaya Regency. Table 2 shows five districts with the most significant number of poor people out of 39 subdistricts located in the Tasikmalaya Regency. Cigalontang sub-district is one of the sub-districts with the highest level of poor population, consisting of 9.837 poor household families with a classification of 4.598 very-poor families, 4.087 poor families, 1.031 near-poor families, and 121 vulnerable poor families. 
Table 2. Number of Poor Households by District and Poverty Classification of Tasikmalaya Regency in 2017 (5 highest order)

\begin{tabular}{lccccc}
\hline \multirow{2}{*}{ Subdistrict } & \multicolumn{3}{l}{ Classification } & Families (Million) & \\
\cline { 2 - 6 } & Very Poor & Poor & $\begin{array}{c}\text { Almost } \\
\text { Poor }\end{array}$ & $\begin{array}{c}\text { Vulnerable } \\
\text { Poor }\end{array}$ & Total \\
\hline Cigalontang & 4.598 & 4.087 & 1.031 & 121 & 9.837 \\
Karangnunggal & 3.149 & 4.295 & 1.353 & 122 & 8.919 \\
Sodonghilir & 3.714 & 3.905 & 1.041 & 126 & 8.786 \\
Cipatujah & 2.746 & 3.619 & 1.554 & 178 & 8.097 \\
Salopa & 2.726 & 3.089 & 1.391 & 248 & 7.454 \\
\hline
\end{tabular}

Source : Social Service, Manpower, and Transmigration Tasikmalaya Regency, 2018.

According to Arsyad (2010), strategies for alleviating poverty, namely through human resource development. Improvement of social services (education, health, and nutrition) is the essential thing to alleviate poverty. Increasing social services provided by the government will increase the productivity of the poor population. The various programs have been carried out to overcome the poverty problems, both by the central government and regional governments. These programs include Prosperous Rice Program or Food Social Assistance, Village Fund Program, Agrarian Reform and Social Forestry Program, Non-Cash Food Aid, Smart Indonesia Program, Healthy Indonesia Program, and Family Hope Program (Situmorang, 2018).

The Family Hope Program is one of the policies aimed at very poor households. The Family Hope Program is aimed at very-poor families. It makes that The Family Hope Program recipients are still allowed to receive other social assistance such as the Smart Indonesia Program and the Healthy Indonesia Program (Social Service, Manpower, and Transmigration Tasikmalaya Regency, 2018).

According to Social Ministry of Republic Indonesia (2018), the Family Hope Program is conditional assistance program for families identified as Beneficiary Families. The Family Hope Program requirements are having children aged 0-18 years (still in elementary school, junior high school, high school), pregnant/postpartum mothers, elderly people $\geq 70$ years old, and disability. The purpose of the Family Hope Program is to reduce poverty and improve the quality of human resources, especially the poor. Specifically, the goal of the Family Hope Program is to improve the socio-economic conditions, education, health, and nutrition status of pregnant women, postpartum mothers, improve access, and quality of education and health services. The The Family Hope Program is internationally known as Conditional Cash Transfer (CCT) and is quite successful in alleviating poverty. Government policy support is essential in poverty alleviation. This condition is in line with the research result of Marmujiono (2014) that the government's commitment is one of the strengths in supporting poverty alleviation efforts.Funds channeled through the The Family Hope Program are part of government expenditure on health and education. According to Suparmoko (2016), government spending can be divided into several groups, namely: Expenses which are investments to add strength and economic resilience in the future, Expenditures that directly provide welfare to the community, Expenditures for future savings in expenses, Expenditures that directly offer more significant employment opportunities.

As conditional assistance, the Family Hope Program prioritizes access to very-poor families, especially pregnant women and children, to get health services and education services. The Family Hope Program began to be encouraged to assist the disabled and elderly.

Through the Family Hope Program, the poor get social access such as health, education, food, and nutrition, including various social protection programs support complementary. 
The Family Hope Program is expected to alleviate poverty by synergizing various social protection and empowerment programs. The number of recipients of the Family Hope Program in the Cigalontang District was 2.855 Beneficiary Families. Of the 16 villages in Cigalontang Sub-district, Cidugaleun Village is the village with the highest number of the Family Hope Program recipients, namely 384 Beneficiary Families (Social Service, Manpower, and Transmigration Tasikmalaya Regency, 2018).

Based on the phenomenon, researchers are interested in analyzing the implementation of the Family Hope Program in the Cigalontang SubDistrict as the region with the most impoverished population in the Tasikmalaya Regency.

This research uses the Benefit Incidence Analysis (BIA) method. Benefit Incidence Analysis (BIA) is a method to measure how government subsidies or taxes can affect people's welfare. In this case, the Benefit Incidence Analysis (BIA) evaluates government spending in the form of grants between groups with different incomes. Although very rough, BIA is a good way to measure who get more benefits from government spending. In the Benefit Incidence Analysis (BIA) method, it is necessary to use descriptive analysis to reflect whether the target beneficiaries are evenly distributed based on demographics (Khan et al., 2017).

The purpose of the Benefit Incidence Analysis (BIA) method is to evaluate a government policy, both subsidies and taxes, in influencing the welfare of the community by utilizing the Lorenz Curve (Khan et al., 2017). The result of the BIA analysis is a measure of whether the government subsidy program is right on target; that is, low-income community groups receive the benefits of the subsidy. The Lorenz Curve and the Concentration Curve can be seen in Figure 1.

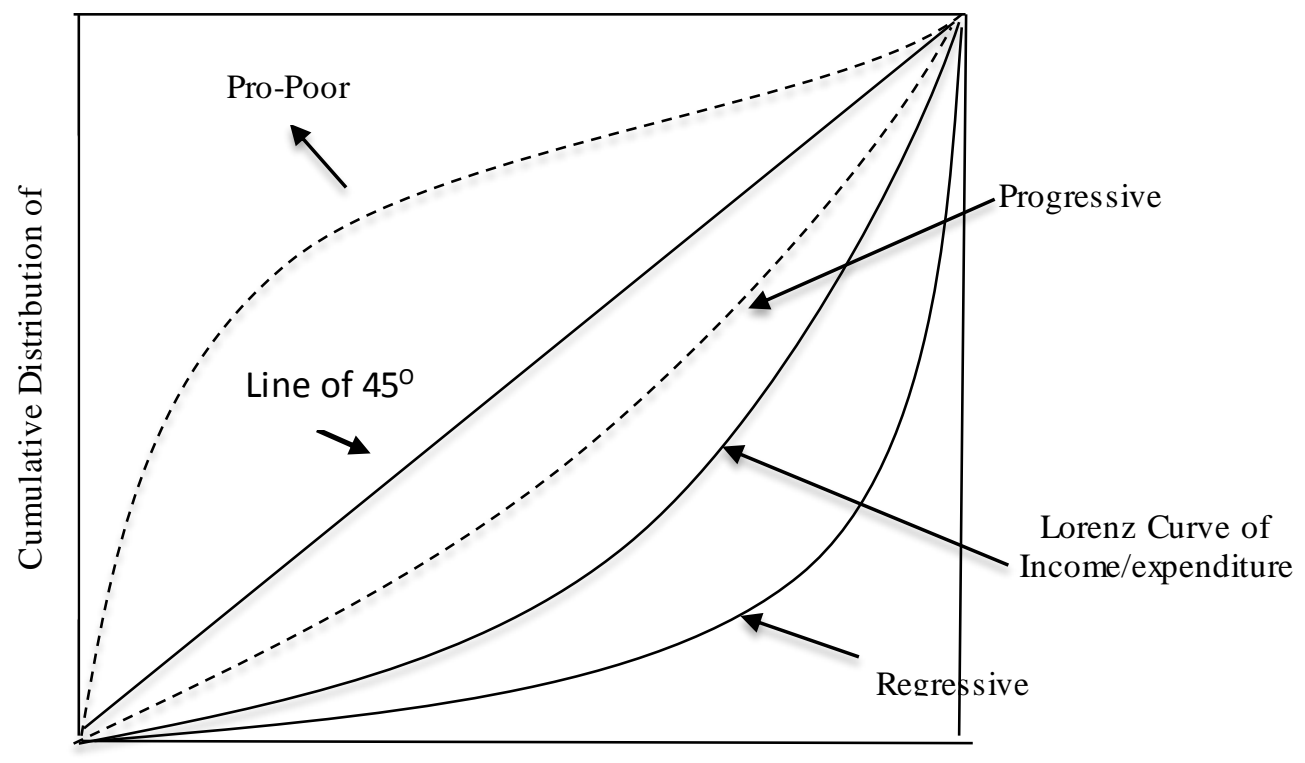

Cumulative Distribution of Population

Figure 1. The Lorenz Curve and The Concentration Curve

This study analyzes how government spending through the Family Hope Program to alleviate poverty in Cigalontang Sub-district, Tasikmalaya Regency with the Benefit Incidence Analysis (BIA). The BIA analyzes how government spending on community welfare is pro-poor, progressive, or regressive. The expenditure is pro-poor if the population in $40 \%$ of the low-income group benefits more than 40 $\%$. The spending is progressive if low-income earners get the most benefit. The expenditure is regressive if only a small portion of low-income 
residents benefit from government spending to alleviate poverty. Based on the results of a preliminary survey conducted in March 2018, it is known that there are some problems in the implementation of the Family Hope Program in the community, including high-income residents who receive the Family Hope Program assistance.

Previous research on poverty alleviation policies has been carried out. Hanif (2016) researching the performance of the Family Hope Program implementation with qualitative descriptive methods, case study approaches; Lidiana et al. (2014) examined the Family Hope Program assistance in its paper with educational participation, Virgoreta et al. (2015) examined the Family Hope Program implementation in improving community welfare, using qualitative descriptive methods. Some researchers also use the Benefit Incidence Analysis (BIA) method, including Hafidh et al. (2014), Khan, et al. (2017), Ashgar \& Zahra (2012), Mujiarti et al. (2016), Okafor \& Ichoku (2015). Their research object focuses on the analysis of government policies related to education.

This study is different from previous studies, namely that this study uses the overall Family Hope Program policy research object, both education and health, in a specific location in a district area. This research is the Family Hope Program policy evaluation seen from the accuracy of the policy implementation objectives, the nature of the policy concerning the distribution of public welfare, and the effectiveness of the policy. The analytical method used in addition to using the BIA also uses the proportion calculation method and the Appraisal Effectiveness Program. This study aims to analyze: (1) the accuracy of the Family Hope Program in achieving its objectives, (2) the characteristics of the Family Hope Program policies in poverty alleviation (pro-poor, progressive or regressive), (3) the effectiveness of the Family Hope Program implementation.

\section{RESEARCH METHODS}

This study uses a survey method, which was conducted in 2018 in the Sub-district of
Cigalontang, Tasikmalaya Regency, West Java. The population of this research is the people who get the Family Hope Program assistance. Based on data from the Social Service, Manpower, and Transmigration Tasikmalaya Regency, the Family Hope Program recipients in Cigalontang Sub-district in 2018 were 2.855 Beneficiary Families. The data used in this study are primary and secondary data. Primary data were obtained by interviews and questionnaires from the Family Hope Program recipients in the Cigalontang Sub-district.

Secondary data were obtained from the Central Statistics Agency and the Social Service, Manpower, and Transmigration Tasikmalaya Regency. The sampling technique used is MultiStage Random Sampling, which is random sampling, and the implementation is done by dividing the population into several fractions. From this faction, samples were taken (Utomo, 2007). The sampling process is carried out in stages, starting with the State, Province, Regency/City, Sub-district, and Village. The village to be sampled in the Cigalontang Subdistrict is Cidugaleun Village. The village was chosen because the highest number of recipients of the Family Hope Program is 384 Beneficiary Families. Determination of the sample in this study using the Slovin formula

$$
n=\frac{N}{1+N e^{2}}
$$

Description : $\mathrm{n}$ is sample size, $\mathrm{N}$ is population size, e is percent allowance for uncertainty due to sampling errors that are still tolerated, in this case, $5 \%$ is used. Based on this formula, the number of respondents examined is as follows:

$$
\begin{aligned}
& n=\frac{N}{1+N e^{2}} \\
& n=\frac{384}{1+384(5 \%)^{2}} \\
& n=\frac{384}{1+384(0.0025)} \\
& n=\frac{384}{1+0.96} \\
& n=\frac{384}{1.96} \\
& n=195
\end{aligned}
$$


The total sample of this research is 195 Beneficiary Families.

The method used in determining whether the Family Hope Program is right on target or not, uses the proportion formula with a descriptive approach. The formula used is as follows:

$$
\text { Proportion }=\frac{x}{n} \times 100 \%
$$

Description : $\mathrm{x}$ is total population below/above the poverty line, $\mathrm{n}$ is overall sample size of the poor population.

The indicator used is the per capita poverty line in the Tasikmalaya Regency in 2017 of Rp. 284,462 (Tasikmalaya Regency in Figures, 2018). The Family Hope Program has been said to be right on target if the proportion of the program recipients who earn below the per capita poverty line is more than the Program recipients who are above the per capita poverty line. Conversely, if there are more the Family Hope Program recipients above the poverty line than the Program recipients below the poverty line, then the pattern of the Family Hope Program reception in the Cigalontang Sub-district is not on target. The Benefit Incidence Analysis method is used to analyze whether the Family Hope Program is a Pro-poor, progressive, or regressive policy for low-income residents.

The BIA method focuses on analyzing whether government spending policies are propoor, progressive, or regressive. Therefore, the BIA combines data between the use of subsidized funds by the community, as well as the cost of providing these funds to measure the distribution of benefits from government spending to be classified based on the amount of income (Hafidz, 2014).

The formula used in the Benefit Incidence Analysis method is as follows (Demery, 2000):

$$
X_{j}=\sum_{k=1}^{n} \frac{E_{i j k}}{E_{i}}\left(\frac{S_{i k}}{S_{i}}\right)=\sum_{k=1}^{n} \sum_{i=1}^{3} s_{i j k} s_{i k}
$$

Description : $\mathrm{X}_{\mathrm{j}}$ is total value of subsidies linked to group (j), $E_{i j k}$ is represents a number of the beneficiary family registered with the group (j), $E_{i}$ is total number of registered (all groups), $S_{i}$ is Government net expenditure on Program.

According to Demery (2000), the Benefit Incidence Analysis (BIA) method consists of three steps, namely: calculate the number of subsidies provided by the government, Identifying recipients of subsidies from the government, Classifying and sorting society based on income or expenditure.

The criterion for determining that government spending (subsidies) is said to be propoor, progressive, or regressive is to use a benefit concentration curve and a perfect line of extraction.Pro-Poor, if the concentration curve is above the perfect equalization line. It means that the population group that is in $40 \%$ of the lowincome group benefits more than $40 \%$,

Progressive, if the concentration curve is below the perfect equalization line but still above the Lorenz curve. It means that people with low incomes get the most benefit. Regressive, if the concentration curve is below the perfect equalization line and at the same time under the Lorenz curve. It means that only a small portion of the low-income population benefits from government expenditure. The Appraisal Effectiveness Program method is used to analyze whether the Family Hope Program is an effective policy. This analysis technique is used to determine the effectiveness of the Family Hope Program. Based on the Report of Government Service 2006 (Australian GovernmentProductivity Commission. 2006), the Australian government defines indicators of the effectiveness of a policy based on agreement, namely access, accuracy or appropriateness, and quality. The access indicator explains whether the Beneficiary Families easily access the Family Hope Program funds on conditions that are easily met or not. Access indicators can be seen from the Program requirements that are easily met, obstacles in the registration process, or the Beneficiary Families data collection that are entitled to receive the Program funding assistance. Indicators of accuracy or appropriateness explain whether the Family 
Hope Program assistance funds have been targeted with Very-Poor Households as their targets and are appropriate for the objectives of the Program funding assistance from the government listed in the mechanism of implementing the Family Hope Program. Indicators of accuracy or appropriateness can be seen from the criteria for the Program beneficiaries following the government's objectives of reducing poverty and improving the quality of human resources, especially the poor.

Quality indicators explain whether the function or usefulness of the Family Hope Program has a significant impact on the beneficiary family. The indicator aims to illustrate the scope of government policies that have been implemented. Quality indicators are seen from the benefits obtained by the beneficiary family after obtaining the Program.

In general, the above indicators focus on measuring changes in results that describe the object of government programs or policies. A government program or policy can be said to be effective if all of the indicators have been met.

\section{RESULTS AND DISCUSSION}

Characteristics of the Family Hope Program Beneficiary Respondents will be described as follows. Based on work, the Family Hope Program recipient jobs vary, namely as laborers, farmers, entrepreneurs, and village officials. There are even respondents who do not have a job due to old age. The majority of family heads work as laborers, i.e., $68 \%$ and $5 \%$ of respondents do not work. Based on Age, the population is devided into two categories, namely productive age and non-productive age. Productive age is the age between $16-64$ years, while non-productive age is the age below 15 years and above 65 years (Central Bureau of Statistics, 2019). The majority of the Family Hope Program recipients (47\%) lived aged between 37-54 years; then, the second-largest was between 18-36 years (39\%). These conditions indicate that the majority of respondents are in the productive age.Based on Level of education, the majority of respondents (89\%) had an elementary school education. In other words, the majority of the Family Hope Program recipients have relatively low education. Even $3 \%$ of them do not go to school.

Based on Number of family dependents, the majority of the Program recipients (52\%) have a number of family dependents between 2-3 people, and $42 \%$ have a number of family dependents between $0-1$ people. While the remaining $6 \%$ have a family dependent between 4-5 people. Based on Recipients of Social Assistance Besides the Family Hope Program, the Family Hope Program is a policy that aims to eradicate very- poor households. Because the Program recipients are very-poor households, they are allowed to receive social assistance other than the Family Hope Program. The Program recipients are recognized to receive social assistance such as Non-Cash Food Aid, Smart Indonesia Program, Healthy Indonesia Program, and free electricity. Respondents who received social assistance other than the Family Hope Program were 170 people (87\%), and those who did not receive social assistance other than the Program were 25 people (13\%).

Table 3. Respondent Data Based On Family Income per Month

\begin{tabular}{|c|c|c|}
\hline Income (IDR) & $\begin{array}{l}\text { Number of Respondent } \\
\text { (Family) }\end{array}$ & Percentage (\%) \\
\hline$\leq 900.000$ & 110 & 56 \\
\hline $900.001-1.800 .000$ & 58 & 29 \\
\hline $1.800 .001-2.700 .000$ & 19 & 10 \\
\hline $2.700 .001-3.600 .000$ & 5 & 3 \\
\hline $3.600 .001-4.500 .000$ & 3 & 2 \\
\hline Total & 195 & 100 \\
\hline
\end{tabular}

Source: Primary Data Processed, 2018 
Based on family income, income is devided into two categories, namely family income and income per capita. Family income is grouped into five categories, sorted from the lowest income to highest one within one month. The Family income of respondent can be seen in Table 3. Tabel 3 explains the pattern of Family Hope Program acceptance based on family income. There are 110 families (56\%) that have family income $\leq$ IDR900.000,00, 58 families (29 $\%)$ that have family income of IDR900.001,00 IDR1.800.000,00, 19 families (10\%) that have family income of IDR1.800.001,00 - IDR $2.700 .000,00,5$ families ( $3 \%$ ) that have family income of IDR 2.700.001,00 - 3.600.000,00, and 3 families ( $2 \%$ ) that have family income of Rp3.600.001,00 - Rp4.500.000,00. The standard of deviation of the income data can be seen in Table 4.

Based on Table 4. the lowest value is IDR 0,00 because there is the elderly people. While the highest value is IDR 4.500.000,00, there is all of the family members are already working.

Table 4. Standard of Deviation of Income per Month

\begin{tabular}{cccccc}
\hline & $\mathbf{N}$ & Min & Max & Mean & $\begin{array}{c}\text { Std. } \\
\text { Deviation }\end{array}$ \\
\hline Income per month & 195 & 0 & 4.500 .000 & 1083589,74 & 779199,587 \\
\hline
\end{tabular}

Source: Primary Data Processed, 2018

The mean value of income per month is 1083589,74 and standard of deviation value is 779199,587. The mean value is more than deviation standard value. It indicates the good data (Sugiyono, 2014). The income per capita of respondent can be seen in Table 5 .

Table 5. Respondent Data Based on Income Per capita

\begin{tabular}{lcc}
\hline \multicolumn{1}{c}{ Income Per Capita (IDR) } & $\begin{array}{c}\text { Number of Respondent } \\
\text { (Family) }\end{array}$ & Percentage (\%) \\
\hline$\leq 250.000$ & 117 & 60 \\
$250.001-500.000$ & 68 & 35 \\
$500.001-750.000$ & 4 & 2 \\
$750.001-1.000 .000$ & 2 & 1 \\
$1.000 .001-1.250 .000$ & 4 & 2 \\
\hline Total & 195 & 100 \\
\hline
\end{tabular}

Source: Primary Data Processed, 2018

Table 5. explains the pattern of Family Hope Program acceptance based on income per capita. There are 117 families (60\%) that have income per capita $\leq$ IDR 250.000,00, 68 families (35\%) that have income of IDR250.001,00 IDR 500.000,00, 4 families (2\%) that have income per capita of IDR 500.001,00 - IDR
750.000,00, 2 families (1\%) that have income per capita of IDR 750.001,00 - IDR 1.000.000,00, and 4 families $(2 \%)$ that have income per capita of IDR 1.000.001,00 - IDR 1.250.000,00. The standard of deviation of the income per capita data can be seen in Table 6 .

Table 6. Standard of Deviation of Income per capita per Month

\begin{tabular}{lccccl}
\hline & $\mathrm{N}$ & Min & Max & Mean & $\begin{array}{l}\text { Std. } \\
\text { Deviation }\end{array}$ \\
\hline Income Per Capita & 195 & 0 & 1.750 .000 & 288173,72 & 242159,471 \\
\hline Source: Primary Data Processed, 2018 & & &
\end{tabular}


Based on Table 6 there are 195 families as beneficiary families. The lowest value is IDR 0 because there is the elderly people. While the highest value is IDR 1.750.000,00, there is all of the family members are already working. The mean value of income per capita is 288173,7179 and deviation standard value is 242159,471 . The mean value is more than deviation standard value. It indicates the good data (Sugiyono,
2014). The description of respondents can also be seen from the amount of family expenses. Family expenses are the expenditures used to buy goods and sevices. The expenditures referred to health and education expenditures for a month. The expenditures are classified into five classes, sorted from the smallest expenses to the highest one. The family expenses can be seen in Table 7 .

Table 7. Respondent Data Based on Family Expenses Per Month

\begin{tabular}{lcc}
\hline Family Expenses (IDR) & $\begin{array}{c}\text { Number of } \\
\text { Respondent (Family) }\end{array}$ & Percentage (\%) \\
\hline $50.000-340.000$ & 83 & 42 \\
$340.001-630.000$ & 74 & 37 \\
$630.001-920.000$ & 24 & 12 \\
$920.001-1.210 .000$ & 13 & 6 \\
$1.210 .001-1.500 .000$ & 1 & 3 \\
\hline Total & 195 & 100 \\
\hline
\end{tabular}

Source: Primary Data Processed, 2018

Table 7 explains the family expenses per month. There are 83 families (4 $2 \%$ ) with the family expenses of IDR 50.000,00-IDR $340.000,00,74$ families (37 \%) with the family expenses of IDR 340.001,00-IDR630.000,00, 24 families (12\%) with the family expenses of IDR
630.001,00- IDR 920.000,00, 13 families (6 \%) with the family expenses of IDR 920.001,00IDR 1.210.000,00, and 1 family (3\%) with the family expenses of IDR 1.210.001,00-IDR 1.500.000,00. The standard of deviation of the family expenses data can be seen in Table 8 .

Table 8. Standard of Deviation of Family Expenses per Month

\begin{tabular}{cccccr}
\hline & $\mathrm{N}$ & Min & Max & Mean & Std. Deviation \\
\hline Family expenses & 195 & 50.000 & 1.500 .000 & 450358,97 & 262166,576 \\
\hline
\end{tabular}

Source: Primary Data Processed, 2018

Based on Table 8 the lowest value of family expenses is IDR 50.000,00. While the highest value is IDR $1.500 .000,00$. The Expenditures are taken only for health and education expenses because according to the focus of Family Hope Program is to improve the health and education of the poor. The mean value of family expenses is 450358,97 and deviation standard value is 262166,576 . The mean value more than deviation standard value.
It indicates the good data (Sugiyono, 2014). The analysis results of accuracy of the Family Hope Program Targets in The Cigalontang Sub-district, will be explained as follows. By using the poverty line per capita indicator in The Tasikmalaya Regency in 2017 of IDR 284.462,00 (Tasikmalaya Regency in Figures, 2018), the results of this study show the income of the Program recipients can be seen in Table 9.

Table 9. Patterns of Family Hope Program Acceptance in Cigalontang District

\begin{tabular}{lcc}
\hline Income (IDR) & $\begin{array}{c}\text { Number of Respondents } \\
\text { (Families) }\end{array}$ & (\%) \\
\hline$\leq$ Rp284.462 & 120 & 62 \\
$>$ Rp284.462 & 75 & 38 \\
\hline Total & 195 & 100 \\
\hline Source: Primary Data Processed, 2018 & &
\end{tabular}

Source: Primary Data Processed, 2018 
Based on the data in Table 9, it can be seen that the pattern of the Family Hope Program acceptance in the Cigalontang Sub-district is right on target. Because the number of people living below the poverty line per capita who get the benefits is more that as many as 120 families (62 $\%$ ), while the population with income that is above the line poverty per capita of 75 families (38\%). Even though there are 75 families (38\%) are above the per capita poverty line, these families meet the Family Hope Program recipient requirements and according to the Integrated Database (BDT), are still eligible to receive the Program. The results show that the implementation of the Family Hope Program receipts was right on target because the poor received the largest proportion of benefits from the Program according to the target of very-poor
Households. The results of this study are not in line with the research result of Hanif (2016) and Khan et al. (2017).

The analysis results of distribution of the Family Hope Program Benefits in The Cigalontang Sub-district, will be explained as follows. The Benefit Incidence Analysis (BIA) method aims to identify the progressiveness nature of the Family Hope Program in the Cigalontang Sub-district. The results of the BIA calculation are shown in Table 10. Based on Table 10, the groups with the lowest expenditure received benefits of $42 \%$, low to medium expenditures received benefits by $37 \%$, medium expenditures received benefits by $12 \%$, medium to high expenditures received benefits by $6 \%$, and the highest expenditure receives benefits of 3 $\%$.

Table 10. Distribution of Benefits of Family Hope Program in Cigalontang District

\begin{tabular}{llc}
\hline Quintile & Class & Benefit Incidence \\
\hline 1 & Lowest expenditure & 0.42 \\
2 & Low - medium expenditure & 0.37 \\
3 & Medium expenditure & 0.12 \\
4 & Medium - high expenditure & 0.06 \\
5 & The highest expenditure & 0.03 \\
\hline Total & & 1 \\
\hline
\end{tabular}

Source: Primary Data Processed, 2018

Note: Lowest expenditure is IDR50.000-IDR $340.000,00$; Low - medium expenditure is IDR 340.001,00-IDR 630.000,00; Medium expenditure is IDR 630.001,00-IDR 920.000,00; Medium - high expenditure is IDR 920.001,00 IDR 1.210.000.00; The highest expenditure is IDR 1.210.001,00-IDR 1.500.000,00

The results of the Benefit Incidence Analysis (BIA) calculation can be divided into three categories, namely, pro-poor, progressive, and regressive. The results of the calculation can be categorized as pro-poor if the benefit concentration curve is above the $45^{\circ}$ line, progressive if the benefit concentration curve is above the Lorenz curve for income or expenditure, but still below the $45^{\circ}$ line. If the benefit concentration curve is below the Lorenz curve and below the $45 \%$ line for income or expenditure, then it can be said that the program is regressive. It can be seen in Figure 2. Figure 2 illustrates the progression curve with a $45^{\circ}$ diagonal line curve as a comparison with the benefit concentration curve obtained from the Benefit Incidence Analysis (BIA). The results obtained from the Benefit Incidence Analysis (BIA) calculations show that the Family Hope Program in The Cigalontang Sub-district is ProPoor and on target because more than $42 \%$ of the total respondents who received the most benefits from the Program were the poor. The results of this study are in line with Hafidh et al. (2014) and Ashgar \& Zahra. (2012) for the provision of subsidies at the level of basic education, but for higher education levels are regressive. But the role of government subsidies for advanced education in Nigeria is progressive (Okafor, \& Ichoku, 2015). 


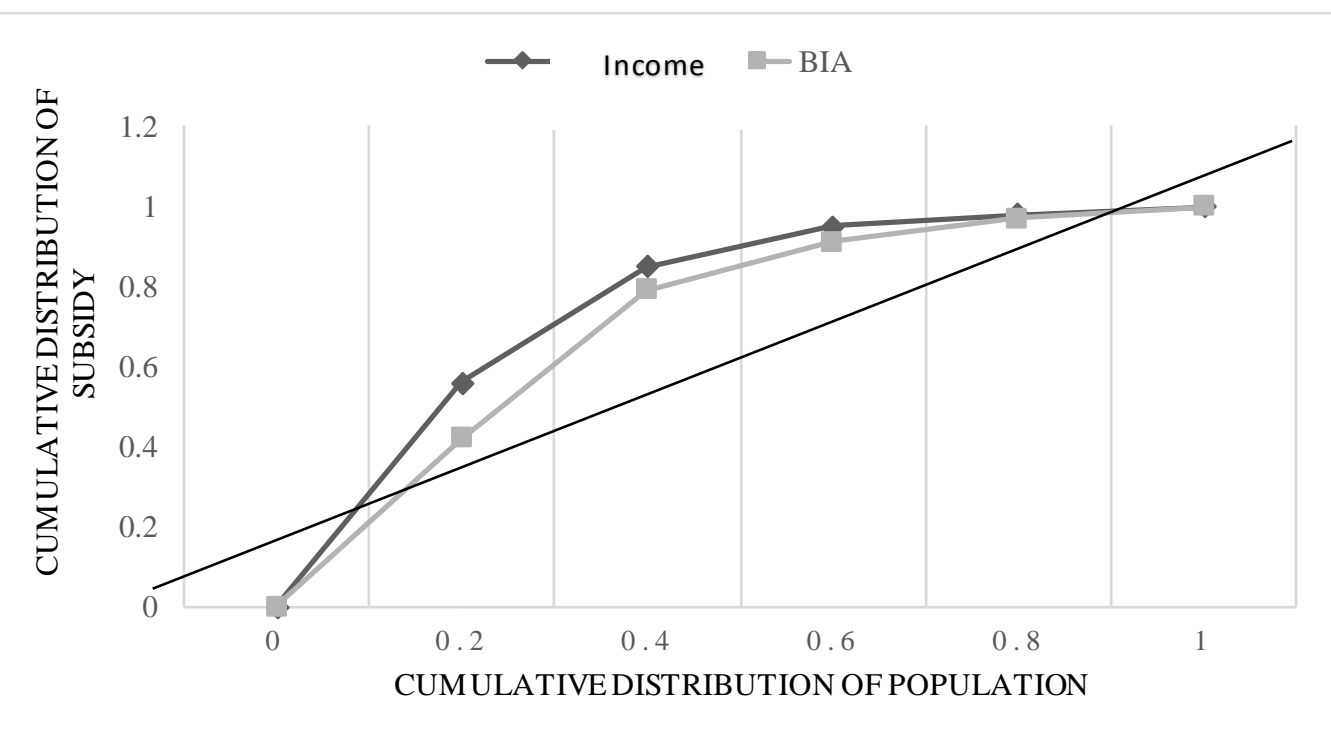

Figure 2. Family Hope Program Progressivity Curve

Source: Primary Data Processed, 2018

The calculation results from the Business Impact Analysis (BIA) are following the theory put forward by Dumairy (1996) that the government must interfere in the economy. There are many things need to be considered to spending manage. There is not enough for the government to only achieve the ultimate goal of the spending policy, but it must think about the targets that will receive the benefit of the policy.

The analysis results of effectiveness of the Family Hope Program Appraisal in Cigalontang Districtt, will be explained as follows. The effectiveness measure of the Family Hope Program in the Cigalontang Sub-district, it is determined by indicators of access, accuracy, and quality. The indicator was obtained from the Report Government Service. Based on The results of interviews with the Program recipients through a questionnaire, a description of the results is as follows.

Related to access indicator, ease of registration of the Family Hope Program in the Cigalontang Sub-district has been fulfilled. The central government has determined prospective recipients of the Program aid funds through the Integrated Database. The Facilitators must collect documents from Beneficiary Families.
The documents including Family Card, Resident Identity Card, other assistance besides the Family Hope Program (if they have it) and fulfill the requirements set by the Program (having children aged 0 - 18 years old or still in elementary school, junior high school, high school, pregnant/postpartum mothers, elderly people $\geq 70$ years, and disability).

After receiving the Program grants, Beneficiary Families are required to meet once a month to conduct an evaluation of the Program Facilitators. Of the 195 respondents, almost all of them met the requirements. They did not experience difficulties in meeting these requirements, only for the elderly $\geq 70$ years of age had difficulties due to age factors (paralyzed, sick) and could not read or write. They did not understand how the process of disbursing funds through an Automatic Teller Machine (ATM) so they cannot withdraw funds independently. But in such conditions, this is an exception by allowing the disbursement process to be represented by children, grandchildren, or other family members. So it can be concluded that the ease of conditions can be said to be fulfilled (Table 11). 
Table 11. Meeting Family Hope Program Requirements

\begin{tabular}{lcc}
\hline Respondent's condition & $\begin{array}{c}\text { Number } \\
\text { (Family) }\end{array}$ & Percentage (\%) \\
\hline Fulfill the requirements & 182 & 93 \\
Not Fulfilling Requirements & 13 & 7 \\
\hline Total & 195 & 100 \\
\hline
\end{tabular}

Source: Primary Data Processed, 2018.

Related to accuracy indicator, the Family Hope Program recipients can be said to be right on target. This condition can be seen from the indicator that the respondents with income below the poverty line per capita get more benefits from the Program, which is 120 families or $62 \%$. In contrast, respondents with income above the poverty line per capita are 75 families or $38 \%$ (Table 9). Although there are 75 families or $38 \%$ are above the per capita poverty line, all of these families meet the requirements to get the Program assistance.

Related to quality indicator, the distribution of the Family Hope Program assistance in The Cigalontang Sub-district has fulfilled the requirements because the Program funds are used for the purposes determined by the government, namely education and health for children and pregnant/postpartum mothers. Beneficiary Families use the Program funds to meet school needs such as buying notebooks, textbooks, school clothes, shoes, and other educational needs, while health needs are used to buy children's milk, health checks for the elderly, and other treatments.

Based on this explanation, a conclusion can be drawn that the Family Hope Program Policy in The Cigalontang Sub-district has been classified as effective. Aspects in the ease of registration, ease of conditions, ease of disbursement, the accuracy of targets, and benefits are almost all met (Table 12).

The results of this study are not in line with the results of research by Mujiarti et al. (2016). The impact of government policies through Program Keluarga Harapan (PKH) on almost all the research results referred to in this study shows a conclusion that the Program Keluarga Harapan $(\mathrm{PKH})$ program is able to reduce overall poverty levels (Lidiana et al. (2014), Virgoreta et al. (2015).

Table 12. Indicators of Family Hope Program Effectiveness in Cigalontang District

\begin{tabular}{lllll}
\hline Indicators & & & & \\
\hline Access & & & Accuracy & Quality \\
\hline Ease of & Ease of Terms & Ease of & Target & The benefits \\
Registration & & Disbursement & accuracy & \\
\hline$\checkmark$ & $\checkmark$ & $\checkmark$ & $\checkmark$
\end{tabular}

Source: Primary Data Processed, 2018

\section{CONCLUSION}

Based on the results of the research, it can be concluded as follows. First, the pattern of the Family Hope Program acceptance in the Cigalontang Sub-district is right on target because the population with the proportion of income below the poverty line per capita receives the most benefits from the Program according to the target of very-poor households. Second, the Family Hope Program in the Cigalontang Subdistrict is Pro-Poor. Third, the Family Hope Program in Cigalontang District is classified as effective. The Family Hope Program in Cigalontang District has been targeted, pro-poor, and effective. But based on the findings in the 
community, there are still some communities that receive the Program assistance; in fact, it does not meet the requirements to receive the Program assistance. Therefore, the government should be more careful in determining the Program recipients. It is feared that this will lead to new problems, namely social jealousy between communities. The government needs to carry out unannounced inspections to go directly to the community because so far, only Facilitators have come down to the community to conduct socialization or if there are problems with the Program.

This study has limitations, namely: first, The Cigalontang Sub-district is a sub-district that is quite extensive because of limited personnel, material, and time, so the researchers used the Multi-Stage Random Sampling method, which only examined one village in Cidugaleun Village. For further research, it will be better if the study adds to a broader scope, such as researching one district. Second, there is a limitation through the questionnaire that the respondent does not answer the real situation, on the grounds that the Program assistance is revoked or reduced. This condition can still be anticipated by reasking the questions to be answered correctly. Further research can use the data source triangulation method to obtain accurate data (Moleong, 2010).

\section{REFERENCES}

Arsyad, L. 2010. Economic Development. Yogyakarta. Institute of Economic Science YKPN.

Asghar, Z., \& Zahra, M. 2012. A Benefit Incidence Analysis of Public Spending on Education in Pakistan Using PLSM Data. The Lahore Journal of Economics, 17 ( 2) (2012). P. 111-136.

Australian Government-Productivity Commission. 2006. Report on Government Service 2006. https://www.pc.gov.au/research/ongoing/re port-on-government-services $/ 2006 / 2006$.

Accessed on August 15, 2018.

Central Statistic Agency. 2018. Tasikmalaya Regency in Figures 2018. (32060.1702). Central Statisic Agency of Tasikmalaya Regency.

Central Statistic Agency. 2018. Cigalontang SubDistrict in Figures 2018. (3210.1841). Central Statistic Agency of Tasikmalaya Regency.

Central Statistic Agency. 2016. Poverty and Inequality. https://www.bps.go.id/subject/23 /kemiskinan-dan-ketimpangan.html. Accessed on August 14, 2018.

Central Statistic Agency. 2017. Total Poor Population by City and District, 2015-2017. https://www.bps.go.

id/dynamictable/2017/08/03/1260/jumlahpenduduk-miskin-menurut-kabupaten-kota2015---2017.html. Accessed on August 14, 2018.

Central Statistic Agency. 2018. Total Poor Population by Province. https://www.bps.go.id/ dynamictable/2016/01/18/1119/jumlahpenduduk-miskin-menurut provinsi-20072018.html, Accessed on August 14, 2018.

Chalid, P. 2006. Development Theory and Issue . Jakarta: Universitas Terbuka.

Demery, L. 2000. Benefit Incidence; a Practitioner's guide, Poverty, and Social Development Group Africa Region. The World Bank.

Social Service, Manpower, and Transmigration Tasikmalaya Regency. 2018. Number of Poor Households by Sub-Districts and Poverty Classification in Tasikmalaya Regency in 2017.

Dumairy. 1996. Indonesian Economy. Jakarta: Erlangga.

Hafidh, A.A, Nurseto, T., \& Ngadiyono. 2014. Benefit Incidence Analysis Bidikmisi Program at Universities in The Special Province of Yogyakarta. Journal Economia, 10 (2) ( 2014). P.120-132.

Hanif, A. 2016. An Analysis of Poverty Reduction Program Based on the Conditional Cash Transfer (CCT) (A Case of the Family Hope Program Implementation). Jurnal Kebijakan dan Administrasi Publik, 20 (1) (2016). P. 56-67. Haughton, J dan Khandker, S.R. 2012. Guidelines on Poverty and Inequlity. Jakarta: Salemba Empat.

Social Ministry of Republic Indonesia. 2018. Family Hope Program. https://pkh.kemsos.go.id/ ?pg=tentangpkh-1. Accessed on October 28, 2018.

Khan, J.A.M., Ahmed S, MacLennan M, Sarker A.R., Sultana, M., Rahman, H. 2017. Benefit Incidence Analysis of Healthcare in Bangladesh - Equity Matters for Universal Health Coverage. Journal of Health Policy and Planning, 32 (30) (2017). P.359-365

Kuncoro, M. 2006. Development Economics: Theory, Problems, and Policies. Yogyakarta: UPP STIM YKPN.

Lidiana, Syechalad, M.N., \& Nasir, M. 2014. The Effect and Effectiveness of Family Hope Program Assistance on Educational 
Participation in Muara Tiga Sub-District, Pidie Regency. Jurnal Ilmu Ekonomi, 2 (2) ( 2014). P. 31-38.

Marmujiono, S.P. 2014. Analysis of Factors Affecting Poverty Rate and Poverty Alleviation Strategies in Brebes Regency, 2009-2011. Economics Development Analysis Journal, 3 (1) (2014). P. 159-172.

Moleong, L.J. 2010. Qualitative Research Methodology (Revised Revision). Bandung: PT. Remaja Rosdakaya.

Mujiarti, I.A.O., Ananda, C.F., \& Susilo. 2016. Benefit Incidence Analysis Public Service in Malang Raya. International Journal of Social and Local Economic Governance, 2 (1) ( 2016). P. 6976.

Okafor, M.I., \& Ichoku, H. E. 2016. Benefit Incidence Analysis of Government Spending on Education in Anambra State, Nigeria. Journal of Economics and Sustainable Development, 6 (14) (2016). P. 37-44.

West Java at a Glance. 2017. https://jabarprov.go.id/. Accessed on August 14, 2018.

Situmorang, A. P. 2018, Oktober - 25. Seeing The Poverty Alleviation Program Since the Soeharto Government to Jokowi. Liputan6. https://www.liputan6.com/bisnis/read/3676 471/melihat-program-pengentasankemiskinan-sejak-pemerintahan-soehartohingga-jokowi.

Sugiyono. 2014. Statistics for Research. Bandung: Alfabeta.

Suparmoko. 2016. State Finance in Theory and Practice. Yogyakarta. BPFE.

Utomo, A.P. 2007. Study of The Effect of Two Stages Cluster Sampling on F-Test Statistics. Jurnal Matematika, Sains, dan Teknologi, 8 (2) (2007).

Virgoreta, D.A., Pratiwi, R.N., \& Suwondo. 2015. Implementation of Family Hope Program in Efforts to Improve Community Welfare (Study in Beji Village, Jenu Sub-District, Tuban Regency). Jurnal Administrasi Publik, 2 (12) (2015). P. 1-6. 